\title{
HLA-Bw4-B*57 and CW*18 alleles are associated with plasma viral load modulation in HIV-1 infected individuals in Salvador, Brazil
}

Authors

Edinete Melo da Silva ${ }^{1,2}$ Angelina Xavier Acosta ${ }^{2,3}$ Eduardo José Melo Santos ${ }^{3}$ Eduardo Martins Netto ${ }^{1}$ Denise Carneiro Lemaire Adriano Silva Oliveira ${ }^{1}$ Carolina Matos Barbosa Maria Teresita Bendicho ${ }^{4}$ Bernardo Galvão-Castro² Carlos Brites ${ }^{1}$

${ }^{1}$ Infectology Research Laboratory of Hospital Universitário Professor Edgard Santos - HUPES UFBA, Brazil

${ }^{2}$ Advanced Laboratory of Public Health - LASP/ CPQGM/FIOCRUZ, Brazil ${ }^{3}$ Department of Pediatrics, School of Medicine, UFBA, Brazill

${ }^{4}$ Laboratory of Immunology of Instituto das Ciências e

Saúde - ICS/UFBA, Salvador BA, Brazil

Laboratory of Humam and Medical Genetics, Biological Sciences Center, UFPA,

Belém - PA, Brazil

Submitted on: $3 / 4 / 2010$ Approved on: 5/21/2010

Correspondence to: Edinete Melo da Silva Laboratório de Pesquisa em Infectologia, Hospital Universitário Professor Edgard Santos

Rua Augusto Viana, S/N-Canela, , $6^{\circ}$ andar, Salvador - Bahia - Brazil CEP: 40110-060

Phone: +55-71-32838126 Fax: +55-71-32472756

E-mail: edinete@yahoo.com

This study was financially supported by Fundação de Amparo a Pesquisa do Estado da Bahia (FAPESB), Salvador, Bahia, and Conselho Nacional de Desenvolvimento Científico e Tecnológico (CNPq/PAPES), Brazil.

We declare no conflict of interest.

\begin{abstract}
Host genetic factors play an important role in mediating resistance to HIV-1 infection and may modify the course of infection. HLA-B alleles (Bw4 epitope; $\mathrm{B}^{\star} 27$ and $\mathrm{B}^{\star} 57$ ) as well as killer cell immunoglobulin-like receptors have been associated with slow progression of HIV-1 infection. Objective: To evaluate the association between serological epitopes HLA-Bw4 and HLA-Bw6 and prognostic markers in AIDS. Methods: 147 HIV-infected individuals in Bahia, Northeast Brazil, were genotyped for HLA class I locus. HLA class I genotyping was performed by hybridization with sequence-specific oligonucleotide probes following amplification of the corresponding HLA-A, HLA-B and HLA-C genes. Statistical analysis was performed using Fisher's exact and ANOVA tests for categorical and continuous variables, respectively. Results: We detected a significant association $\left(\chi^{2}=4.856 ; \mathrm{p}=0.018\right)$ between the presence of HLA-Bw4 and low levels of viremia. Eighteen out of the $147 \mathrm{HIV}$-infected individuals presented viremia $\leq 1,800$ copies/mL and 129 presented viremia $>2,000$ copies/mL. Ninety and four percent (17/18) of all individuals with viremia $\leq 1,800$ copies/ mL carried HLA-Bw4, compared to $67.4 \%$ (87/129) of individuals with viremia $>2,000$ copies $/ \mathrm{mL}$. Additionally, we found a significantly higher frequency of $\mathrm{B}^{\star} 57(\mathrm{OR}=13.94 ; 95 \% \mathrm{CI}=4.19-46.38$; $\mathrm{p}$ $<0.0001)$ and $\mathrm{Cw}^{\star} 18(\mathrm{OR}=16.15 ; 95 \% \mathrm{CI}=3.46-75.43 ; \mathrm{p} \leq 0.0001)$ alleles, favoring the group with lower viremia levels, in comparison with those with higher viral load. Conclusion: HLA-Bw4-B ${ }^{\star} 57$ and $\mathrm{Cw}^{\star} 18$ alleles are associated with lower level of viral load in HIV-infected Brazilian patients. These findings may help us in understanding the determinants of HIV evolution in Brazilian patients, as well as in providing important information on immune response correlates of protection for such population.
\end{abstract}

Keywords: HIV, AIDS, MHC, HLA, polymorphism.

[Braz J Infect Dis 2010;14(5):468-475]@Elsevier Editora Ltda.

\section{INTRODUCTION}

The dynamics of HIV-1 replication is a very important factor in determining the clinical course of HIV-1 disease. Although an enhanced production of virus particles results in progressive deterioration of the immune system in most HIV-1 infected individuals, the control of viremia and the rate of progression of HIV-1 disease have been demonstrated to be substantially influenced by host genetic characteristics.

The genetic profile of human leukocyte antigen (HLA) class I molecules plays a very important role in both, the innate and adaptative immune responses during the course of HIV-1 infection. Cytotoxic T lymphocyte (CTL) response depends on the recognition of viral peptides presented in association with major histocompatibility (MHC) class I molecules on the surface of infected cells. ${ }^{1}$ Certain types of $H L A-B$ alleles, especially $B^{\star} 27$ and $B^{\star} 57$, seems to strongly influence AIDS progression. ${ }^{2-6} \mathrm{HIV}$-specific CTL play a central role in the initial control of virus replication during primary HIV infection, when the immunologic response limits the viral replication and reduces the viremia and the number of infected cells in lymph nodes, ${ }^{7-10}$ as well as during chronic HIV infection, since the high number of HIV-specific CTL often persists in late infection in peripheral blood of HIV-infected patients. ${ }^{11,12}$ Several studies reported that in HIV-infected long-term survivors the viral load and the number of $\mathrm{CD}^{+} \mathrm{T}$ cells infected with HIV-1 are very low, and a strong HIV-specific CTL response is detected during the course of infection. ${ }^{13,14}$ 
The HLA repertoire can be implicated in the innate immunity responses. HLA class I molecules have been identified as killer immunoglobulin receptor (KIR) ligands. ${ }^{15,16}$ In particular, all HLA-B specificities are grouped in two antigenic families: HLA-Bw4 and HLA-Bw6. ${ }^{17}$ HLA-Bw4 and HLA-Bw6 epitopes consist of a single epitope in each HLA-B molecule and they are different from the epitopes that establish the $H L A-B$ specificity; therefore each $H L A-B$ molecule expresses only one of the serological epitopes HLA-Bw4 or HLA-Bw6. HLA-Bw4 is one of the inhibitory or activating ligands for $\mathrm{KIR}^{18,19}$ that control the natural killer $(\mathrm{NK})$ cell cytotoxic activity. As a component of the innate immune system NK cells might have a very important role in the defense of the HIV-1 infected host, ${ }^{20}$ possibly controlling the viremia through lysis of HIV-infected cells. ${ }^{21,22}$ Genetic association studies and functional assays report the importance of HLABw4 in the pathogenesis of AIDS. Two studies have shown the protective role of HLA-Bw4 against HIV-disease progression through association with viremia control and $\mathrm{CD}^{+} \mathrm{T}$ cell count maintenance. ${ }^{21,23}$ Qi et $a^{24}$ reported the synergistic role of KIR3DS1/Bw4-80Ile against $\mathrm{CD}^{+} \mathrm{T}$ cell depletion and development of opportunistic infections. A more recent study has demonstrated that the presence of $H L A-B w 4$ is associated with a decreased risk in male-to-female HIV-1 transmission. ${ }^{25}$ The objective of this study was to evaluate the association between serological epitopes HLA-Bw4 and HLA-Bw6 and the modulation of viral load and $\mathrm{CD}^{+} \mathrm{T}$ cell count in the Brazilian HIV-infected patients.

\section{MATERIAL AND METHODS}

\section{Subjects}

Were evaluated $147 \mathrm{HIV}$-infected individuals, selected from an AIDS cohort established at the Hospital Universitário Professor Edgard Santos (HUPES) and Centro de Referência Estadual de AIDS (CREAIDS) in 1997 with HIV positive patients from the state of Bahia, Northeast Brazil. All the patients had a Western Blot-confirmed HIV-1 infection. The cohort was monitored for $\mathrm{CD}^{+}$and $\mathrm{CD}^{+} \mathrm{T}$ cell count (cells/ $\mathrm{mm}^{3}$ ) and plasma viral load (copies/mL) every six months. The demographic and clinical parameters of all patients are summarized in Table 1. In Bahia state, there is a great genetic mixture of Portuguese and African descendents. ${ }^{26-28}$ Informed consent for blood donation and for genetic polymorphism investigation was obtained from each patient. This study was approved by the Comitê de Ética em Pesquisa do Centro de Pesquisa Gonçalo Moniz, Process \# 29/2003.

A subset of the patients (18 individuals) was classified as viremia controllers, in accordance with the HIV Controller Consortium. ${ }^{29}$ All controllers had been infected for more than two years, remained asymptomatic during the follow up without antiretroviral therapy and maintained the viral load $\leq 1,800$ copies $/ \mathrm{mL}$. The patients that did not attained to all these criteria (129 individuals) were classified as viremia non-controllers.
Table 1. Demographic and clinical characteristics of HIV-infected individuals in Bahia

\begin{tabular}{lc}
\hline Features & $\begin{array}{c}\text { All patients } \\
(\mathbf{n}=\mathbf{1 4 7})\end{array}$ \\
\hline Age, mean & $45(24-68)$ \\
\hline Sex & \\
Male (\%) & 60.1 \\
Female (\%) & 39.9 \\
\hline Risk of HIV infection & \\
Homosexual (\%) & 19.6 \\
Heterosexual (\%) & 65.2 \\
Blood transfusion(\%) & 3.1 \\
IDV (\%) & 3.9 \\
Bisexual (\%) & 7.6 \\
Unknown (\%) & 7.6 \\
CD4+ T cell count (cells $\left./ \mathrm{m}^{3}\right)$, mean \pm SD & $303 \pm 228$ \\
Viral load (copies $/ \mathrm{mL}), \mathrm{mean}^{+} \mathrm{SD}$ & $107,841 \pm 198,925$ \\
\hline
\end{tabular}

\section{HLA and KIR genotyping}

Genomic DNA was extracted from whole blood using extraction method GFX ${ }^{\mathrm{TM}}$ Kits Genomic Blood DNA Purification (Amersham Pharmacia Biotech, UK). HLA genotyping was performed by using SSO LABType ${ }^{(\mathrm{R})}$ method (ONE LAMBDA, Inc., Canoga Park, USA) according to the manufacturer's instructions. Briefly, the polymerase chain reaction (PCR) conditions were: $96^{\circ} \mathrm{C}$ for 3 minutes, followed by 5 cycles of $96^{\circ} \mathrm{C}$ for 20 seconds, $60^{\circ} \mathrm{C}$ for 20 seconds and $72^{\circ} \mathrm{C}$ for 20 seconds, and 30 cycles of $96^{\circ} \mathrm{C}$ for 10 seconds, $60^{\circ} \mathrm{C}$ for 15 seconds and $72^{\circ} \mathrm{C}$ for 20 seconds, and extend at $72^{\circ} \mathrm{C}$ for 10 minutes. After amplification of genomic DNA using locus-specific primers that flanked exon two and three, PCR products were denatured and annealed to sequence-specific oligonucleotide ( $\mathrm{SSO}$ ) probes of the corresponding $H L A-A,-B$ and $-C$ genes. The fluorescent intensity of binding probes was identified by LABScan ${ }^{\mathrm{TM}} 100$ flow analyzer and the results were interpreted using HLA-visual software that established the HLA genotyping. HLA-A and $H L A-B$ alleles were pooled HLA-Bw4 and HLA-Bw6 according to HLA class I sequence alignments ${ }^{30}$ (Table 2). KIR3DS1 and KIR3DL1 genotyping was performed by using gene-specific primer pairs according to Martin et al. ${ }^{21}$ Each reaction contained $15 \mathrm{ng}$ of DNA, $0.1 \mathrm{mM}$ DNTPs, 1.5 $\mathrm{mM} \mathrm{MgCl}$, 67 mM Tris- $\mathrm{HCl}$ ( $\mathrm{pH} 8.8$ ), 16 mM (NH4)2SO4, $0.25 \mathrm{mM}$ of each primer, and $1 \mathrm{U}$ of Taq polymerase in a $10 \mu \mathrm{L}$ final volume. To improve the reliability of the results, besides the utilization of an internal control, all negative reactions were repeated to confirm non-amplification in the PCR. In addition, positive results were randomly replicated. Phenotype frequencies (f) for the presence of each gene were estimated by direct counting. 
Table 2. Bw4 and Bw6 epitopes and their corresponding alleles observed in the HIV-infected individuals in Bahia

\begin{tabular}{|c|c|c|c|c|c|c|}
\hline $\begin{array}{l}\text { Serological } \\
\text { epitope }\end{array}$ & $\begin{array}{l}\text { Amino-acid } \\
\text { at position }\end{array}$ & & & & & Corresponding alleles \\
\hline & 77 & 80 & 81 & 82 & 83 & \\
\hline \multirow[t]{6}{*}{$B w 4$} & Asn & Ile & Ala & Leu & Arg & 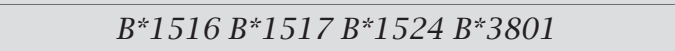 \\
\hline & & & & & & $B^{*} 4901 B^{* 51}$ \\
\hline & & & & & & $B * 5201 B * 53 B * 57 B^{*} 58 A * 23 A * 24$ \\
\hline & Asn & Thr & Ala & Leu & Arg & $B^{*} 13 B^{*} 44$ \\
\hline & Asp & Thr & Leu & Leu & Arg & $B * 2703 B * 2713 B * 3701$ \\
\hline & Ser & Ile & Ala & Leu & Arg & $A * 32$ \\
\hline \multirow[t]{4}{*}{$B w 6$} & Ser & Asn & Leu & Arg & Gly & $B^{*} 07 B^{*} 0801 B^{*} 1401 B^{*} 1402 B^{*} 1501 B^{*} 1502$ \\
\hline & & & & & & $B * 1503 B^{*} 1504 B^{*} 1507 B^{*} 1510 B^{*} 1520$ \\
\hline & & & & & & $B^{*} 1554 B^{*} 1801 B^{*} 1820 B^{*} 35 B^{*} 39 B^{*} 4001$ \\
\hline & & & & & & $B * 4001 B * 41 B * 42 B * 4501 B * 5001 B * 55 B * 8101$ \\
\hline
\end{tabular}

\section{Statistical analysis}

Mean viral load and $\mathrm{CD} 4^{+} \mathrm{T}$ cells count for each patient (before starting antiretroviral therapy) was estimated and used as representative value in the statistical analysis. ANOVA and Mann-Whitney tests were used to compare continuous variables. Fisher's exact test was used to investigate associations between categorical variables and correction for multiple tests was applied when necessary. Hardy-Weinberg Equilibrium analysis was performed for each population (controllers and non-controllers of viremia) using Genepop software. ${ }^{31}$ Additionally, Odds Ratio (OR), and their 95\% confidence interval was used to determine the strength of the allele-specific associations that were statistically significant.

\section{RESULTS}

We detected a direct correlation between viral load and $\mathrm{CD} 4^{+}$ $\mathrm{T}$ cell count, fundamental markers for HIV-infected patient monitoring. It was statistically significant $(R=-0.307$; $\mathrm{p}<0.001$, by Pearson's correlation) and the regression analysis suggested there was a logarithmic relationship between both variables.

\section{Effects of HLA-Bw4 on viral load and $\mathrm{CD}^{+}{ }^{+} \mathrm{T}$ cell count modulation}

Viral load averages for $B w 4, B w 4 / B w 6$ and $B w 6$ phenotypes are shown in Figure 1, which emphases the increasing

Figure 1: HLA-Bw4 presence associated with low levels of plasmatic viral load. Viral load average was calculated for 147 HIV-infected individuals and is shown on the top of the respective bars.

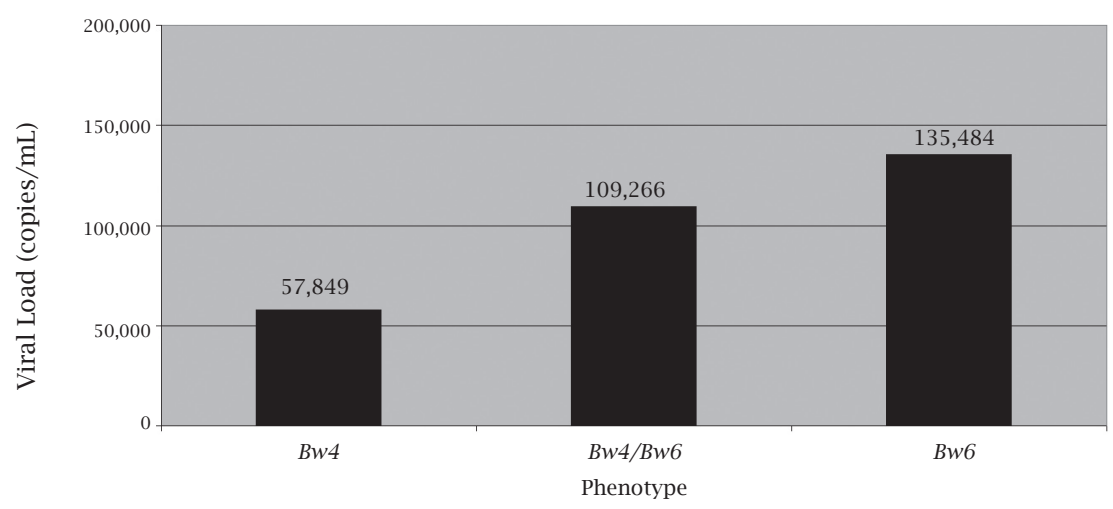


gradient from absence of $H L A-B w 6$ to presence of HLA-Bw4. ANOVA test showed a borderline significant difference between and within the groups that was lost after correction $(\mathrm{p}=0.059 ; \mathrm{pc}=0.076)($ Table 3$)$. The categorization into $B w 4^{+}(B w 4 / B w / 4$ and $B w 4 / B w 6)$ and $B w 4^{-}(B w 6 /$ $B w 6)$ patients groups yielded a more significant association. Mann-Whitney test revealed a statistically significant difference between $B w 4^{+}$and $B w 4^{-}$groups, suggesting an association of the presence of $H L A-B w 4$ with viral load reduction $(\mathrm{Z}=-2.052 ; \mathrm{p}=0.040)$ (Table 3$)$. Additionally, we observed that 18 out of the $147 \mathrm{HIV}$-infected individuals presented viremia $\leq 1,800$ copies $/ \mathrm{mL}$ and 129 presented viremia $>$ 2,000 copies/mL. Ninety four percent (17/18) of all individuals with viremia $\leq 1,800$ copies/mL carried $H L A-B w 4$, compared to $67.4 \%(87 / 129)$ of individuals with viremia
$>$ 2,000 copies/mL (Table 4). We detected a statistically significant association $(\mathrm{OR}=8.21 ; 95 \% \mathrm{CI}=1.08-63.76$; $\mathrm{p}=0.018$; Fisher's exact test) between the presence of $H L A-B w 4$ and low levels of viremia.

The same comparative analysis used for viral load was used for $\mathrm{CD}^{+} \mathrm{T}$ cell count average (Figure 2). Although individuals presenting $B w 4^{+}$had a higher mean $\mathrm{CD}^{+} \mathrm{T}$ cell count than individuals not presenting this allele, the comparison of the groups revealed no significant association between the presence of HLA-Bw4 and higher $\mathrm{CD} 4^{+} \mathrm{T}$ cell count $(\mathrm{p}=0.282)$, even after stratifying patients into $B w 4^{+}(B w 4 / B w / 4$ and $B w 4 / B w 6)$ and Bw4- $(B w 6 / B w 6)$ groups $(\mathrm{Z}=1.220 ; \mathrm{p}=0.222)$ (Table 3 ), suggesting no influence of $H L A-B w 4$ on $\mathrm{CD}^{+} \mathrm{T}$ cell count modulation.

Table 3. Genetic factors associated with clinical markers in HIV-infected patients without antiretroviral therapy

\begin{tabular}{|c|c|c|c|c|c|c|}
\hline Genotype & $\begin{array}{l}\text { Patients } \\
(\mathrm{n}=147)\end{array}$ & Clinical markers & & Clinical markers & & \\
\hline & & $\begin{array}{c}{ }^{\mathrm{a}} \mathrm{CD} 4{ }^{+} \text {count, } \\
\text { cells } / \mathrm{mm}^{3}\end{array}$ & $\begin{array}{c}{ }^{\mathrm{b}} \mathrm{p} \\
\text { value }\end{array}$ & $\begin{array}{l}\text { aViral Load, } \\
\text { RNA copies/mL }\end{array}$ & $\begin{array}{l}{ }^{\mathrm{b}} \mathrm{p} \\
\text { value }\end{array}$ & $\begin{array}{c}{ }^{\mathrm{c}} \mathrm{pc} \\
\text { value }\end{array}$ \\
\hline$H L A B w 4 / B w 4$ & $26(17.7)$ & $363(233)$ & 0.282 & $57,849(81,414)$ & 0.059 & 0.076 \\
\hline$H L A B w 4 / B w 6$ & $78(53.1)$ & $295(226)$ & & $109,266(221,885)$ & & \\
\hline$H L A B w 6 / B w 6$ & $43(29.2)$ & $282(227)$ & & $135,484(202,527)$ & & \\
\hline$B w 4^{+}(B w 4 / B w 4 ; B w 4 / B w 6)$ & $104(70.7)$ & $315(228)$ & 0.222 & $96,411(197,268)$ & 0.040 & \\
\hline$B w 4(B w 6 / B w 6)$ & $43(29.2)$ & $282(227)$ & & $135,484(202,527)$ & & \\
\hline Bw $4^{+}$non- $-B^{*} 27$ & $102(69.4)$ & $317(230)$ & 0.698 & $84,115(147,066)$ & 0.044 & \\
\hline$B w 4^{+}$non- $-B^{*} 57$ & $89(60.5)$ & $312(230)$ & 0.781 & $93,523(153,732)$ & 0.201 & \\
\hline$B w 4^{+}$non- $B^{*} 27$ non $-B * 57$ & $87(59.2)$ & $315(231)$ & 0.721 & $93,990(154,644)$ & 0.194 & \\
\hline Bw $4^{+}-$Ile $80^{+}$ & $80(76.9)$ & $319(240)$ & 0.792 & $105,455(219,144)$ & 0.966 & \\
\hline Bw4+-Ile $80^{-}$ & $24(23.1)$ & $288(184)$ & & $66,297(89,930)$ & & \\
\hline KIR3DL1 & $107(72.8)$ & $303(233)$ & 0.875 & $104,035(163,404)$ & 0.360 & \\
\hline KIR3DS1 & $32(21.8)$ & 297 (199) & & $141,678(303,066)$ & & \\
\hline${ }^{\mathrm{d} N}$ Non KIR3DL1-3DS1 & $08(5.4)$ & $376(279)$ & & $16,054(21,926)$ & & \\
\hline KIR $3 D L 1+B w 4^{+}$Ile $80^{+}$ & $62(59.6)$ & $320(243)$ & 0.923 & $92,632(171,015)$ & 0.354 & 0.934 \\
\hline KIR $3 D L 1+B w 4^{+}$Ile $80^{-}$ & $15(14.4)$ & 303 (193) & & $86,802(108,495)$ & & \\
\hline KIR3DS1+Bw4+ Ile $80^{+}$ & $19(18.3)$ & $302(215)$ & & $183,544(362,791)$ & & \\
\hline KIR $3 D S 1+B w 4^{+}$Ile 80 & $08(7.7)$ & 265 (176) & & $44,174(51,328)$ & & \\
\hline
\end{tabular}

${ }^{\mathrm{a}}$ Mean $\pm \mathrm{SD}$; ${ }^{\mathrm{b}} \mathrm{p}$ values were computed using Mann-Whitney, ANOVA and the $\chi^{2}$ Tests. ${ }^{\mathrm{p} p c}$ values were computed using KruskalWallis Test. ${ }^{\mathrm{d}}$ Non considered in the analysis. 
Figure 2: HLA-Bw4 presence associated with high levels of $\mathrm{CD}^{+} \mathrm{T}$ cell count. CD4 ${ }^{+} \mathrm{T}$ cell count average was calculated for 147 HIV-infected individuals and is shown on top of the respective bars.

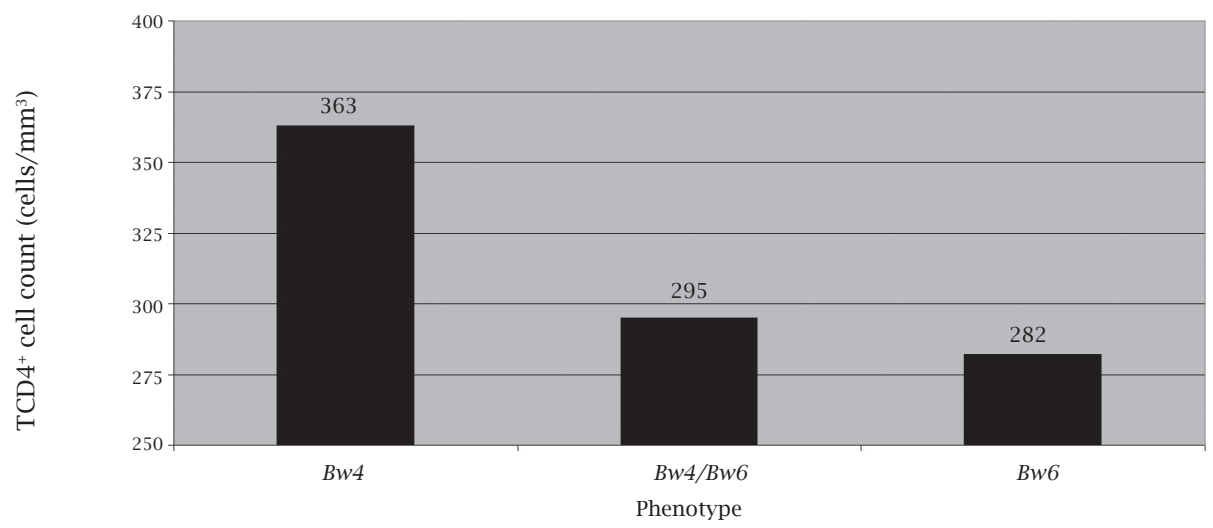

Table 4. HLA and KIR genotype in $147 \mathrm{HIV}$-1 infected patients according to control of viremia

\begin{tabular}{|c|c|c|c|c|}
\hline Genotype & $\begin{array}{l}\text { Controller of viremia (n/\%) } \\
\qquad(\mathrm{n}=18)\end{array}$ & $\begin{array}{l}\text { Non-controller of viremia (n/\%) } \\
\qquad(n=129)\end{array}$ & $\begin{array}{c}\mathbf{p} \\
\text { value }^{\mathrm{a}}\end{array}$ & OR (95\% CI) \\
\hline HLA Bw4/Bw4 & $04(22.2)$ & $22(17.0)$ & 0.020 & \\
\hline$H L A B w 4 / B w 6$ & $13(72.2)$ & $65(50.4)$ & & \\
\hline HLA Bw6/Bw6 & $01(5.5)$ & $42(32.5)$ & & \\
\hline$B w 4^{+}(B w 4 / B w 4 ; B w 4 / B w 6)$ & $17(94.4)$ & $87(67.4)$ & 0.018 & $8.21(1.08-63.76)$ \\
\hline$B w 4(B w 6 / B w 6)$ & $01(5.5)$ & $42(32.5)$ & & \\
\hline Bw $4^{+}$-Ile $80^{+}$ & $13(76.5)$ & $67(77.0)$ & 0.790 & $0.97(0.28-3.31)$ \\
\hline Bw4+-Ile $80^{-}$ & $04(23.5)$ & $20(23.0)$ & & \\
\hline KIR3DL1 & $14(77.8)$ & $93(72.1)$ & 0.287 & $2.26(0.49-10.51)$ \\
\hline KIR3DS1 & $02(11.1)$ & $30(23.2)$ & & \\
\hline${ }^{\mathrm{b}}$ Non $3 D L 1^{+}-3 D S 1^{+}$ & $02(11.1)$ & $06(4.6)$ & & \\
\hline KIR3DL1+Bw4 $4^{+}{\text {Ile } 80^{+}}^{+}$ & $11(64.7)$ & $48(55.2)$ & 0.313 & \\
\hline KIR3DL1+Bw4+ Ile80- & $02(11.7)$ & $12(13.8)$ & & \\
\hline KIR3DS1+Bw4+ Ile $80^{+}$ & $01(5.9)$ & $15(17.2)$ & & \\
\hline KIR3DS1+Bw4+ Ile80- & $01(5.9)$ & $06(6.9)$ & & \\
\hline${ }^{\mathrm{b}} \mathrm{Non} 3 \mathrm{DL} 1^{+}-3 D S 1^{+}+B w 4^{+}$ & $02(11.7)$ & $06(6.9)$ & & \\
\hline \multicolumn{5}{|l|}{ Loci/allele } \\
\hline$H L A-A$ & - & - & 0.828 & \\
\hline \multicolumn{5}{|l|}{$H L A-B$} \\
\hline$B * 27$ & $1(5.5)$ & $1(0.8)$ & 0.100 & $7.53(0.45-126.02)$ \\
\hline$B * 57$ & $8(44.4)$ & $7(5.4)$ & $<0.0001$ & $13.94(4.19-46.38)$ \\
\hline \multicolumn{5}{|l|}{$H L A-C$} \\
\hline$C w^{*} 18$ & $05(27.8)$ & $03(2.3)$ & $<0.0001$ & $16.15(3.46-75.43)$ \\
\hline
\end{tabular}

Note: OR, Odds ratio; CI, confidence interval. ${ }^{\mathrm{p}} \mathrm{p}$ values were computed using Fisher's exact test; ${ }^{\mathrm{b}}$ Non considered in the analysis. 


\section{Protective $B^{\star} 57$ and $C w^{\star} 18$ alleles in the viremia controller}

HLA class I alleles play a role in the biology of both NK and CTL responses, in the control of viral load levels. To evaluate the influence of $H L A$ class I alleles in viremia control we compared the frequencies of HLA-A, HLA-B, and HLA-C alleles for viremia controller and non-controller groups. No significant deviations from Hardy-Weinberg equilibrium were found in all loci analyzed: HLA-A ( $\mathrm{p}=0.33), H L A-B$ $(\mathrm{p}=0.34)$, and $H L A-C(\mathrm{p}=0.30)$. No statistically significant difference for $H L A-A$ allele frequencies was found between the groups $(\mathrm{p}=0.828)$ (Table 4$)$. However, we detected a significant difference in the $B^{*} 57(\mathrm{OR}=13.94 ; 95 \%$ $\mathrm{CI}=4.19-46.38 ; \mathrm{p}<0.0001)$ and $C w^{\star} 18(\mathrm{OR}=16.15 ; 95 \%$ $\mathrm{CI}=3.46-75.43 ; \mathrm{p}<0.0001)$ allele frequencies, which were relatively more frequent in the viremia controller than in non-controller group (Table 4 ). These data suggest a protective role of the $B^{\star} 57$ and $C w^{*} 18$ alleles in the control of viral load. Curiously, $100 \%$ of $C w^{*} 18$ carriers (5/5) that control the viremia are also $B^{\star} 57$ carriers, while this last allele was found in $66.7 \%(2 / 3)$ of the non-controller group.

\section{Influence of $H L A-B^{\star} 57$ allele in the protection conferred by $H L A-B w 4$}

Genetic and functional studies have shown a protective effect of $H L A$ class I alleles, in particular $B^{\star} 27$ and $B^{\star} 57$, in the HIV disease progression. These alleles belong to the HLA-B Bw4 group. In order to evaluate the effects on NK and CTL responses to that regard, we analyzed the role of $H L A-B w 4$ on HIV disease progression markers in the presence and absence of $B^{\star} 27$ and $B^{\star} 57$ alleles. The protective effect of $H L A-B w 4$ remained significantly upon removal of the individual positive for $B^{\star} 27(\mathrm{p}=0.044)$, but was entirely lost in the absence of $B^{\star} 57(\mathrm{p}=0.201)$ (Table 3$)$, indicating that the protection conferred by HLA-Bw4 is completely dependent on the presence of $B^{\star} 57$.

\section{Effects of KIR3DS1/3DL1 on viral load and CD4 ${ }^{+} \mathrm{T}$ cell count modulation}

HLA-Bw4 molecules with isoleucine at position 80 (Bw480Ile) are ligands for inhibitory KIR3DL1 receptors and Bw4-80Ile in combination with the activating KIR3DS1 found to result in delayed progression to AIDS. To assess the effect of the alleles Bw4-80Ile, KIR3DL1 and KIR3DS1 on viral load and $\mathrm{CD}^{+} \mathrm{T}$ cell count modulation we analyzed their distribution in this population. Initially, we compared the viral load and $\mathrm{CD} 4^{+} \mathrm{T}$ cell average between the patients $B w 4-80 I \mathrm{Ie}^{+}$ (80Ile/80Ile or 80Ile/80Thr) and Bw4-80Ile- (80Thr/80Thr) (Table 3). We observed a non protective influence of Bw4-80Ile on viral load $(\mathrm{p}=0.687)$ or $\mathrm{CD}^{+} \mathrm{T}$ cell count $(\mathrm{p}=0.687)$ modulation. Next, we compared the frequencies of Bw4-80Ile and Bw4-80Thr in the viremia controllers and non-controllers groups (Table 4). We found no statistically significant difference between the groups $(\mathrm{p}=0.790)$. This result may suggest that the association of $H L A-B w 4$ with viral load reduction in the HIV-1 infection found here is not specifically attributed to the Bw4-80Ile. The influence of KIR3DL1 and KIR3DS1 subtypes on clinical markers modulation was also tested: KIR3DL1 and KIR3DS1 were carried by $72.8 \%(107 / 147)$ and $21.8 \%(35 / 147)$ of patients, respectively. Eight patients (5.4\%) who were negative for KIR3DL1 and KIR3DS1 were not included in the analysis (Table 3). We did not find any significant association between the presence or absence of KIR3DL1/KIR3DS1 genotype and the clinical markers of HIV-1 infection (Tables 3 and 4). We observed that all patients who carried protective $B^{\star} 57$ and $C w^{*} 18$ $\left(B^{\star} 57=15 / 147 ; B^{\star} 57-C w^{*} 18=7 / 15 ; C w^{*} 18=8 / 147\right)$ alleles also carried KIR3DL1, but carried no KIR3DS1. These data suggest no effect of KIR3DS1/3DL1 genotype on viral load and $\mathrm{CD} 4^{+} \mathrm{T}$ cell count modulation.

\section{DISCUSSION}

Previous findings have shown the important role of cellular immunity in controlling HIV-1 replication., ${ }^{8,10,11,32}$ HIV-specific CTL, selected according to HLA class I repertoire associated to viral peptides, can control the viral replication efficiently through lysis of infected cells before new viral particles arise..$^{14}$ In this study $H L A-A$ and $H L A-B$ alleles were grouped according to serological antigens $H L A-B w 4$ and HLA-Bw6 (Table 2). Some studies have reported the important influence of HLA-Bw4 in HIV-1 pathogenesis. Martin et al (2002) demonstrated epistatic interaction between KIR3DS1/Bw4-80Ile and delayed progression to AIDS by genetic analysis. ${ }^{21}$ Qi et al have demonstrated that KIR3DS1/ Bw4-80Ile genotype is involved directly in the protection against HIV-1, controlling the viral load through lysis of infected cells, and/or indirectly preventing or delaying the onset of opportunistic infections. ${ }^{24}$ This corroborates our findings.

Here, we observed an association between HLA-Bw4 and viral load reduction. The $H L A-B w 4$ phenotype seems to modulate the viral load levels, when considering the whole infected population (Figure 1 and Table 3). Ninety four percent of these patients, who consistently presented viral load levels $\leq 1,800$ copies $/ \mathrm{mL}$, during a period of 2 to 12 years without antiretroviral therapy, carried $H L A-B w 4$, which confirms the protective role of this specific allele for HIV-infected individuals. However, the protective influence of $H L A-B w 4$ on the control of viremia is completely dependent on the presence of $B^{\star} 57$ allele (Table 3 ), a finding that confirm the already reported favorable effect of $B^{\star} 57$ on HIV-1 viral load. ${ }^{6}$

Beyond the $B^{\star} 27$ and $B^{\star} 57$, HLA-C alleles can play an important role in the HIV/AIDS context. Lazaryan et al have demonstrated that $C w^{*} 18$ allele is associated with lower viral load among all subjects with and without $B^{\star} 5703$ in the Zambian cohort. ${ }^{33}$ In our study, $27.8 \%$ of the viremia 
controllers individuals carried $C w^{\star} 18$ allele, which was significantly associated with lower viral load levels, suggesting a protector effect on HIV-1 infection in this population. As $100 \%(5 / 5)$ of controllers of viremia individuals who carried $C w^{*} 18$ also carried $B^{\star} 57$ and these alleles are in linkage disequilibrium it is possible to attribute the protective effect of $C w^{*} 18$ to the presence of $B^{\star} 57$. Theoretically, the role of $C w^{\star} 18$ and $H L A-B w 4 / B^{\star} 57$ may be independent, although it can be involved in the same context to produce effective NK and CTL responses.

$H L A-B w 4$ epitope and HLA-C allotypes are ligands for NK cell receptors KIR3DL1/3DS1 and KIR2DL1/2DL2/2DL3, respectively $y^{34}$ and stimulate its cytotoxic activity that is complementary to CTL responses. Inhibitory KIR3DL1 and activating KIR3DS1 receptors can play a protective effect on AIDS progression in the presence of HLA Bw4-80Ile ligand in the infected cell. ${ }^{21,35}$ Inhibitory KIR3DL1 allele highly expressed on the cell enhance protection conferred by HLA $B w 4-80 I l e$ allele, including $B^{\star} 57$ specifically. ${ }^{35}$ In our work HLA Bw4-80Ile, KIR3DL1 and KIR3DS1 alleles had no influence in the modulation of clinical markers in HIV-1 infection, even in face of high KIR3DL1 (72.8\%) and moderate KIR3DS1 (21.8\%) expression.

Involvement of $C w^{*} 18$ in $\mathrm{NK}$ cell activity will not be discussed here because we did not verify the distribution of KIR2DL(1-3) receptors to HLA-C allotypes, and therefore it is beyond the scope of this work. We cannot define the exact mechanism by means both populations of $\mathrm{T}$ lymphocytes (CTL and NK) might modulate the virus level in favor of the host. However, once the pivotal role of CTL is influenced by the $H L A$ profile, we could suggest that the allelic groups of HLA-B that compound the HLA-Bw4 group and HLA$C w^{*} 18$ allele are specific and more efficient in presenting peptides of circulating viral variants in this population, being able to produce an effective cellular immune responses. In addition, according to our results, it is possible to suggest that HLA-Bw4 and $H L A-C w^{*} 18$ might function as activators of NK cell cytotoxic activity to destroy HIV-infected cells, which represent one of the main viral reservoirs. As a consequence of the destruction of these reservoirs mediated by combined CTL and NK activity, the plasmatic viral levels would decrease. Obviously, functional assays would be necessary to confirm this hypothesis.

Our data not only confirm the findings of other studies, in different populations, but also reinforce the important influence of the MHC polymorphisms in HIV/AIDS natural history, regardless the ethnic groups. It is very important to emphasize that the Brazilian urban populations are quite heterogeneous in terms of ethnic/genetic structure, and unique (a wide genetic mixture involving Amerindians, Portuguese and Africans), ${ }^{26-28,36}$ when compared to other populations around the world. Bahia, in particular, has a bigger genetic contribution of Africans and Portuguese, ${ }^{26-28}$ what becomes genetically different of the populations from other regions of Brazil. Additionally, environmental factors involved in HIV infection, such as social-economic and cultural factors, are also particular to this specific Brazilian region (Bahia), which resembles African countries, not only due to its genetic composition but also to social structure, culture, and health problems. ${ }^{28,37}$ Therefore, we could deduce that the profile of the association found here will be able to serve as orientation foretells for politics of public health, with reference to infection/illness prevention, and that the HLA profile of the studied patients can be used for therapeutic monitoring in order to improve the effectiveness of the AIDS treatment.

\section{CONCLUSIONS}

HLA-Bw4-B $B^{\star} 57$ and $C w^{\star} 18$ alleles are associated with lower level of viral load in HIV-infected patients from Bahia. This is the first study to demonstrate that serological epitopes HLA-Bw4 and HLA class I alleles are associated with disease progression markers in HIV-1 infection involving patients from Bahia, and provides important information about how the host genetic factors influence the AIDS clinical course.

Taken together, these findings may help us in understanding the determinants of HIV evolution in Brazilian patients, as well as in providing important information on immune response correlates of protection for such population. The prevention of the AIDS development in the Bahia population will reduce the costs with medicines that are necessary for who has already developed the disease. However, it is necessary to confirm these data through a study with a larger number of samples.

\section{ACKNOWLEDGMENTS}

We thank the HUPES and CREAIDS outpatient clinics, and all the patients for their participation in this study.

\section{REFERENCES}

1. Abbas K. Complexo de histocompatibilidade principal. In: Abbas K., Lichtman A.H., Pober J.S.eds. Biologia celular e molecular. Rio de Janeiro: Revinter, 1995.

2. Magierowska M, Theodorou I, Debré P et al. Combined genotypes of CCR5, CCR2, SDF1, and HLA genes can predict the long-term nonprogressor status in human immunodeficiency virus-1 infected individuals. Blood 1999; 93:936-41.

3. Migueles SA, Sabbaghian MS, Shupert WL et al. HLAB ${ }^{\star 5701}$ is highly associated with restriction of virus replication in a subgroup of HIV-infected long term nonprogressors. Proc Natl Acad Sci USA 2000, 97:2709-14.

4. Kaslow RA, Rivers C, Tang J et al. Polimorphisms in HLA class I genes associated with both favorable prognosis of human immunodeficiency virus (HIV) type I infection and positive cytotoxic T-lymphocyte responses to ALVAC-HIV recombinant canarypox vaccines. J Virol 2001; 75:8681-9. 
5. Altfeld M, Addo MM, Rosenberg ES et al. Influence of HLAB57 on clinical presentation and viral control during acute HIV-1 infection. AIDS 2003; 17:2581-91.

6. López-Vázquez A, Mina-Blanco A, Martinéz-Borra J et al. Interaction between KIR3DL1 and HLA-B ${ }^{\star} 57$ supertype alleles influences the progression of HIV-1 infection in a Zambian population. Hum Immunol 2005; 66:285-9.

7. Pantaleo G, Graziosi C, Demarest JF et al. HIV infection is active and progressive in lymphoid tissue during the clinically latent stage of disease. Nature 1993; 362:355-8.

8. Pantaleo G, Fauci AS. New concepts in the immunopathogenesis of HIV infection. Annu Rev Immunol 1995; 13:487-512.

9. Borrow P, Lewicki H, Wei X et al. Antiviral pressure exerted by HIV-1-specific cytotoxic T lymphocytes (CTLs) during primary infection demonstrated by rapid selection of CTL escape virus. Nat Med 1997; 3:205-11.

10. Koup RA, Safrit JT, Cao Y et al. Temporal association of cellular immune responses with the initial control of viremia in primary human immunodeficiency virus type 1 syndrome. J Virol 1994; 68:4650-5.

11. Rinaldo C, Huang X, Fan $Z$ et al. High levels of anti-human immunodeficiency virus type 1 (HIV-1) memory cytotoxic Tlymphocyte activity and low viral load are associated with lack of disese in HIV-1-infected long-term nonprogressors. J Virol 1995; 69:5838-42.

12. Chen Y, Rinaldo C, Gupta P. A semiquantitative assay for $\mathrm{CD}^{+}$ T-cell-mediated suppression of human immunodeficiency virus type 1 infection. Clin Diagn Lab Immunol 1997; 4:4-10.

13. Cao Y, Qin L, Zhang L, et al. Virologic and immunologic characterization of long-term survivors of human immunodeficiency virus type 1 infection. New Engl J Med 1995; 332:201-8.

14. Harrer T, Harrer E, Kalams SA et al. Citotoxic T lymphocytes in asymptomatic long-term nonprogressing HIV-1 infection: Breadth and specificity of the response and relation to in vivo viral quasispecies in a person with prolonged infection and low viral load. J Immunol 1996; 156:2616-23.

15. Winter CC, Gumperz JE, Parham P, Long EO, Wagtmann N. Direct binding and functional transfer of NK cell inhibitory receptors reveal novel patterns of HLA-C allotype recognition. J Immunol 1998; 161:571-7.

16. Wagtmann N, Rajagopalan S, Winter CC et al. Killer cell inhibitory receptors specific for HLA-C and HLA-B identified by direct binding and by functional transfer. Immunity 1995; 3:801-9.

17. Muller CA, Engler-Blum G, Gekeler V et al. Genetic and serological heterogeneity of the supertypic HLA-B locus specificities Bw4 and Bw6. Immunogenetics 1989; 30:200-7.

18. Cella M, Longo A, Ferrara GB, Strominger JL, Colonna M. NK3-specific natural killer cells are selectively inhibited by Bw4-positive HLA alleles with isoleucine 80. J Exp Med 1994; 180:1235-42.

19. Gumperz JE, Litwin V, Phillips JH et al. The Bw4 public epitope of HLA-B molecules confers reactivity with natural killer cell clones that express NKB1, a putative HLA receptor. J Exp Med 1995; 181:1133-44.
20. Bruunsgaard H, Pedersen C, Skinhoj P, Pedersen BK. Clinical progression of HIV infection: Role of NK cells. Scand J Immunol 1997; 46:91-5.

21. Martin MP, Gao X, Lee J et al. Epistatic interaction between KIR3DS1 and HLA-B delays the progression to AIDS. Nat Genet 2002; 31:429-34.

22. Hultström AL, Bratt G, Cosma A et al. Autologous cytotoxicity of natural killer cells derived from HIV-infected patients. Immunol Letters 2004; 91:155-8.

23. Flores-Villanueva PO, Yunis EJ, Delgado JC et al. Control of HIV-1 viremia and protection from AIDS are associated with HLA-Bw4 homozygosity. Proc Natl Acad Sci USA 2001; 98:5140-5.

24. Qi Y, Martin MP, Gao X et al. KIR/HLA pleiotropism: protection against both HIV and opportunistic infections. Plos Pathogens 2006; 2:741-5.

25. Welzel TM, Gao X, Pfeiffer RM et al. HLA-B Bw4 alleles and HIV-1 transmission in heterosexual couples. AIDS 2007; 21:225-9.

26. Alves-Silva J, Santos MS, Guimarães PEM et al. The ancestry of Brazilian mtDNA lineages. Am J Human Genet 2000; 67:44461.

27. Carvalho-Silva DR, Santos FR, Rocha J, Pena SDJ. The phylogeography of Brazilian Y-chromosome lineages. Am J Hum Genet 2001; 68:281-6.

28. Abe-Sandes K, Silva Jr WA, Zago MA. Heterogeneity of the $Y$ chromosome in Afro-Brazilian populations. Human Biology 2004; 76:77-86.

29. Walker BD. Elite control of HIV infection: implications for vaccines and treatments. International AIDS Society 2007; 15:134-6.

30. HLA Class I Sequence Alignments [http://www.anthonynolan. org.uk/HIG/data.html]

31. Raymond M, Rousset F. Population genetics software for exact-tests and ecumenicism. Genepop version 1.2. J Hered 1995; 86:248-9.

32. Schmitz JE, Kuroda MJ, Santra S et al. Control of viremia in simian immunodeficiency virus infection by CD8+ lymphocytes. Science 1999; 283:857-60.

33. Lazaryan A, Lobashevsky E, Mulenga J et al. Human leukocyte antigen B58 supertype and human immunodeficiency virus type 1 infection in native africans. J Virol 2006; 80:6056-60.

34. Bashirova AA, Martin MP, McVicar DW et al. The killer immunoglobulin-like receptor gene cluster: tuning the genome for defense. Annu Rev Genomics Hum Genet 2006; 7:277300 .

35. Martin MP, Qi Y, Gao X et al. Innate partnership of HLA-B and KIR3DL1 subtypes against HIV-1. Nat Genet 2007; 39:733-40.

36. Carvalho-Silva DR, Tarazona-Santos E, Rocha J et al. Y chromosome diversity in Brazilians: switching perspectives from slow to fast envolving markers. Genetica 2006; 126:251-60.

37. Barbosa AAL, Sousa SMB, Abe-Sandes K et al. Microsatellite studies on an isolated population of African descent in the Brazilian state of Bahia. Genet Mol Biol 2006; 29:23-30. 